\title{
Inoculum Dynamics, Fruit Infection, and Development of Brown Rot in Prune Orchards in California
}

\author{
Yong Luo, Themis J. Michailides, David P. Morgan, William H. Krueger, and Richard P. Buchner
}

First, second, and third authors: Department of Plant Pathology, University of California-Davis, Kearney Agricultural Center, Parlier 93648; fourth author: University of California, Cooperative Extension Center, Glenn County, Orland 95963; and fifth author: University of California, Cooperative Extension Center, Tehama County, Red Bluff 96080.

Accepted for publication 19 May 2005.

\begin{abstract}
Luo, Y., Michailides, T. J., Morgan, P. D., Krueger, W. H., and Buchner, R. P. 2005. Inoculum dynamics, fruit infection, and development of brown rot in prune orchards in California. Phytopathology 95:1132-1136.

Brown rot, caused by Monilinia fructicola, is a destructive disease of stone fruit in California. Disease management requires information on inoculum dynamics and development of latent and visible fruit infections during the season to help make decisions on timing of fungicide treatments and choice of cultural practices. In this study, the daily spore concentration (ascospores and conidia) of $M$. fructicola in the air was monitored with spore traps in two prune orchards during the growing

in midseason increased spore concentration in the air and fruit infections late in the season. Artificial fruit inoculations were conducted periodically in 10 prune orchards in 2002 and 2004, and incidence of fruit rot at different inoculation dates was assessed. Fruit rot development rate increased linearly with inoculation date during the growing season. Natural blossom and fruit infections were monitored periodically in 10 prune orchards, and incidence of latent fruit infection was determined by using the overnight freezing-incubation technique. Incidence of fruit rot also was assessed 2 weeks before harvest in these orchards. The incidence of latent fruit infection at the pit hardening stage significantly correlated with that at the late stages and with the incidence of fruit rot at harvest.
\end{abstract} seasons in 2001 and 2002. The spore concentrations were low to moderate at early bloom, increased at full bloom, and decreased to the lowest level at the end of bloom. Improper timing of fruit thinning and irrigation
Additional keywords: decision support.
Blossom blight and fruit rot caused by Monilinia fructicola (3) are two main phases of brown rot of stone fruit in California. Under favorable weather conditions, ascospores produced in apothecia from mummified fruit on the orchard floor or conidia in sporodochia of infected mummified fruit on trees can serve as inoculum sources for blossom blight in the spring $(1,6,8,9,11,24)$. Under unfavorable conditions, these primary infections can remain latent in the blossoms and immature fruit $(4,22,26)$. Both visible and latent infections of fruit can continue during mid- and late season. After bloom, the main inoculum source in California stone fruit orchards are conidia of $M$. fructicola from infected fruit dropped onto the orchard floor at thinning $(7,17)$. Under favorable conditions in mid- and late season, latent infections of fruit can lead to fruit rot.

Management of blossom blight involves reducing the risk of blossom infection in the spring (18). After bloom, reducing the risk of fruit infection is also of major importance. Estimation of possible risk of fruit infection should be based on the understanding of seasonal patterns of fruit susceptibility and factors affecting fruit infection (14), the relationship between inoculum and environment in orchards (12), and the threshold conditions that lead from latent infection to fruit rot (16). Proper timings of fungicide application, fruit thinning, and irrigation are three major considerations in brown rot management (17). Therefore, understanding how inoculum changes during the season, as affected by other cultural practices in orchards, can help determine the best time period to assess latent infection levels on immature fruit in

Corresponding authors: Y. Luo; E-mail address: yluo@uckac.edu T. J. Michailides; E-mail address: themis@uckac.edu

DOI: 10.1094/PHYTO-95-1132

(C) 2005 The American Phytopathological Society early or midseason. In addition, once the latent infection level in an orchard is determined, one needs to estimate the possible risk of fruit rot at harvest. Thus, how latent infection develops during the season to fruit rot becomes an important question for disease management. The answer will help in making decisions on timing of fungicide applications in mid- and late season. Determination of latent infection in orchards has become technically feasible $(20,21)$ and the threshold conditions leading from latent infection to fruit rot have been identified (16); therefore, determination of fruit infection once at the best time period in the season may be feasible and practically acceptable to growers.

In this study, we conducted field experiments to obtain the information needed to improve our existing decision support system for management of brown rot of stone fruit in California (13). The objectives of this study were to determine (i) inoculum dynamics as spore concentration in the air during the season, (ii) fruit latent and visible infection development during the season, and (iii) possible correlations among blossom and fruit latent infections at different time periods in the season and those with fruit rot at harvest.

\section{MATERIALS AND METHODS}

Inoculum dynamics. Two prune orchards with a history of severe brown rot, orchard 1 in Glenn County and orchard 2 in Tehama County, were selected in 2001. In 2002, two other prune orchards with a history of low disease, orchard 3 in Glenn County and orchard 4 in Tehama County, were added to this study. No fungicide sprays were applied in any of these orchards. A spore trap (Burkard Manufacturing Co. Ltd, Rickmansworth, Hertfordshire, UK) was placed at a height of $1.5 \mathrm{~m}$ from the ground in each orchard, corresponding to the middle of the tree canopy. The sticky tape used to capture spores was replaced weekly. The tape 
was cut into daily segments which were examined every other day. For each examined segment, the whole area was scanned with a microscope $(\times 250)$ and the total number of $M$. fructicola ascospores and conidia on the entire tape was counted. The daily spore concentration in the air was monitored from 6 March to 15 August in orchard 1 and from 5 March to 20 April (when the grower discontinued the cooperation agreement) in orchard 2 in 2001, and from 20 March to 2 August in orchards 3 and 4 in 2002. The spore concentration in the air (spores per liter of air) was calculated using the formula provided by the manufacturer. A plot of spore concentration versus sampling dates was obtained for each orchard. In addition to the size and shape of ascospores and conidia, identification of M. fructicola spores also was confirmed by culturing spores from the tapes onto acidified $(2.6 \mathrm{ml}$ of a $25 \% \mathrm{vol} / \mathrm{vol}$ lactic acid solution per liter) potato dextrose agar (APDA). The area under the spore-concentration plot from 20 March through 15 April (AUSCP1) was determined in each orchard in each year to represent spore concentration in spring, and that from 16 April through 31 July (AUSCP2) was determined to represent the spore concentration in mid- and late season.

Approximately 500 to 700 blossoms per orchard were collected randomly at full bloom on 12 April 2001 from orchards 1 and 2 and on 11 April 2002 from orchards 3 and 4, and $\approx 300$ immature fruit per orchard were collected randomly on 22 July 2001 from orchards 1 and 2 and on 18 July 2002 from orchards 3 and 4 . Samples of blossoms and fruit were processed using the methods described below to determine the incidence of latent infection of blossoms and fruit.

Fruit inoculation experiments. An isolate of $M$. fructicola collected from a prune orchard was cultured in petri dishes that contained APDA and incubated at $23 \pm 2{ }^{\circ} \mathrm{C}$ for 5 days in the dark. The pathogen then was subcultured on new petri dishes under the same conditions for 5 days. Conidia of $M$. fructicola were harvested by pouring $3 \mathrm{ml}$ of sterile distilled water into each petri dish, and the spore concentration of the suspension was adjusted to $5,000 \mathrm{spores} / \mathrm{ml}$ with a hemacytometer.

In 2002 and 2004, immature fruit were inoculated artificially in 10 prune orchards located in Tulare, Fresno, Madera, Yuba, Butte, Sutter, Glenn, and Tehama counties, representing areas with significant commercial prune acreage. Fungicides were not applied in any of the experimental plots in these orchards. Inoculations were conducted at different fruit development stages in two to four trees per orchard. In each tree, 5 to 10 branches, each bearing 30 to 40 fruit, were selected, and each fruit was inoculated by injecting $\approx 0.1 \mathrm{ml}$ of a conidial suspension of $M$. fructicola into the fruit at a depth of $5 \mathrm{~mm}$. In all, 20 branches were used on each inoculation date in each orchard. The inoculated fruit were maintained on the trees until harvest. On each inoculation date, the number of fruit with brown rot for each inoculated branch from the previous inoculation dates was assessed, and the incidence (\%) of fruit rot for each inoculated branch was calculated. The inoculation dates with the corresponding growth stages and disease assessment dates are listed in Table 1.
The average incidence of fruit rot (IFR) for each orchard was determined from the 20 inoculated branches. These values were used to calculate the mean IFR from all 10 orchards on each disease assessment date, and the data of the mean IFR and disease assessment date were used to plot fruit rot development curves.

For each inoculation, the fruit rot development rate $(r)$ was calculated by using the following equation (27): $r=(\ln [100 /(100-$ $\left.\left.\left.\mathrm{IFR}_{2}\right)\right]-\ln \left[100 /\left(100-\mathrm{IFR}_{1}\right)\right]\right) /\left(t_{2}-t_{1}\right)$, where $\mathrm{IFR}_{2}$ and $\mathrm{IFR}_{1}$ are the incidence levels of fruit rot on dates $t_{2}$ and $t_{1}$, respectively. Based on the logistic growth of fruit rot development curves, the time interval between $t_{1}$ and $t_{2}$ was determined from the time period between the inoculation date and the date on which the curve reached the end of exponential growth or the maximum of IFR. Thus, the time intervals $(\Delta t)$ between $t_{1}$ and $t_{2}$ were 60 (2002) and 56 (2004) days for the first inoculation, 50 (2002) and 40 (2004) days for the second inoculation, and 20 days (2002 and 2004) for the third, fourth, and fifth inoculations. The $r$ value for each inoculation interval was determined for each orchard, and a mean $r$ value $\left(r_{m}\right)$ for each inoculation in each year was calculated across all orchards. For each year, a linear regression analysis between $r_{m}$ and the corresponding inoculation date in terms of days after full bloom was conducted by using the REG procedure of SAS (version 8.0; SAS Institute, Cary, NC).

Natural infection of blossoms and fruit. Natural infection of blossoms and fruit was monitored in the above 10 prune orchards in 2003 and 2004. At full bloom (15 to $20 \mathrm{March}$ ), 500 to 700 blossoms were collected arbitrarily from 7 to 10 trees in each orchard. Blossoms were soaked in $500 \mathrm{ml}$ of $1 \%$ commercial bleach $(0.525 \%$ sodium hypochlorite) for $3 \mathrm{~min}$ and washed with sterilized water five times each for $2 \mathrm{~min}$. Plastic containers (40 by 24 by $12 \mathrm{~cm}$ ) were sterilized by washing them twice with $10 \%$ bleach. Two layers of wet paper towels were placed on the bottom of each container. Approximately 60 to 70 blossoms were placed individually on top of the wet paper towels in each container that was covered to maintain high relative humidity $(>95 \%)$. The blossoms were incubated at 23 to $25^{\circ} \mathrm{C}$ for 5 to 7 days. The incidence of blossom infection was calculated as the number of infected blossoms (blossoms showing typical sporulation of $M$. fructicola on the peduncle) divided by the total number of incubated blossoms in each container.

In each orchard, $\approx 200$ immature fruit each were collected at pit hardening (early May), embryo growth (late May to early June), late embryo growth (late June), before ripeness (mid July), and before first harvest (early August) in each year. The overnightfreezing incubation technique $(20,21)$ was used to determine the incidence of fruit with latent infection. In this process, plastic containers ( 40 by 24 by $12 \mathrm{~cm}$ ) and screens were sterilized by soaking in $10 \%$ bleach for at least $8 \mathrm{~h}$. Fruit were surface disinfested in a chlorine solution $(32 \mathrm{ml}$ of $0.525 \%$ sodium hypochlorite, $32 \mathrm{ml} \mathrm{95 \%} \mathrm{ETOH,} \mathrm{and} 0.01 \mathrm{ml}$ Tween 20 in 2 liters of water) for 10 to $15 \mathrm{~min}$. Fruit then were washed with sterile distilled water and placed on a disinfested plastic screen in a container with $150 \mathrm{ml}$ of water at the bottom. The containers were

TABLE 1. Description of field experiments in which individual prune fruit were injected with a conidial suspension of Monilinia fructicola and subsequently monitored for brown rot development in 10 prune orchards in California

\begin{tabular}{|c|c|c|c|c|c|c|c|c|c|c|}
\hline & \multicolumn{10}{|c|}{ Periodic inoculation } \\
\hline & \multicolumn{5}{|c|}{2002} & \multicolumn{5}{|c|}{2004} \\
\hline & First & Second & Third & Fourth & Fifth & First & Second & Third & Fourth & Fifth \\
\hline
\end{tabular}

a $\mathrm{PH}=$ pit hardening, $\mathrm{EG}=$ embryo growth, $\mathrm{BR}=$ before ripeness. 
placed in a freezer at $-16^{\circ} \mathrm{C}$ for $10 \mathrm{~h}$ and then incubated on a laboratory bench at $23 \pm 2^{\circ} \mathrm{C}$ for 5 days. By this time, fruit showing abundant sporulation of $M$. fructicola were counted to determine the incidence of latent infection of fruit.

On 20 to 21 August 2003 and 16 to 17 August 2004, approximately at harvest time, 20 trees were selected arbitrarily in each of the sampling orchards. The incidence of visible fruit rot in each tree was assessed and the mean incidence of fruit rot was calculated for each orchard.

The data from orchards showing no disease at all stages of bloom, immature fruit, and harvest were eliminated from data analysis. Because fewer than 10 sample sets were available for each year, 2 years of data were combined to obtain 15 complete data sets for analysis. Mean incidence of latent infection of blossoms or fruit was calculated from the replicated samples in each orchard for each sampling date. Using mean incidence levels from the 15 orchard-year combinations, correlations in incidence of latent infection of blossoms or fruit and incidence of visible fruit rot between any two sampling dates were implemented with the CORR procedure of SAS.

TABLE 2. Area under the spore-concentration plot (AUSCP) in spring and summer and incidence levels of blossom and latent fruit infections by Monilinia fructicola in prune orchards in California ${ }^{\mathrm{a}}$

\begin{tabular}{lcccc}
\hline & & & \multicolumn{2}{c}{ Incidence of infection } \\
\cline { 4 - 5 } Year, orchard & AUSCP1 & AUSCP2 & Blossom $(\%)^{\mathrm{b}}$ & Fruit (latent \% $)^{\mathrm{c}}$ \\
\hline 2001 & & & & \\
Orchard 1 & 376.9 & 1,366 & $12.0( \pm 1.4)$ & $38.5 \pm 5$ \\
Orchard 2 & 141.7 & $\ldots$ & $4.0( \pm 0.6)$ & $\ldots$ \\
2002 & & & & \\
Orchard 3 & 305.8 & 90.6 & $3.0( \pm 3.0)$ & 0 \\
Orchard 4 & 200.8 & 161.7 & $0.24( \pm 0.1)$ & 0 \\
\hline
\end{tabular}

a ... Indicates missing data. AUSCP1 and $-2=20$ March to 15 April and 16 April to 31 July, respectively.

${ }^{\mathrm{b}}$ Incidence of blossom infection was recorded on 12 April 2001 for orchards 1 and 2 and 11 April 2002 for orchards 3 and 4. Numbers in parentheses represent standard errors of the mean based on 7 to 10 replicates.

${ }^{\mathrm{c}}$ Latent infection was determined with samples of immature fruit collected on 22 July 2001 from orchards 1 and 2 and 18 July 2002 from orchards 3 and 4 .

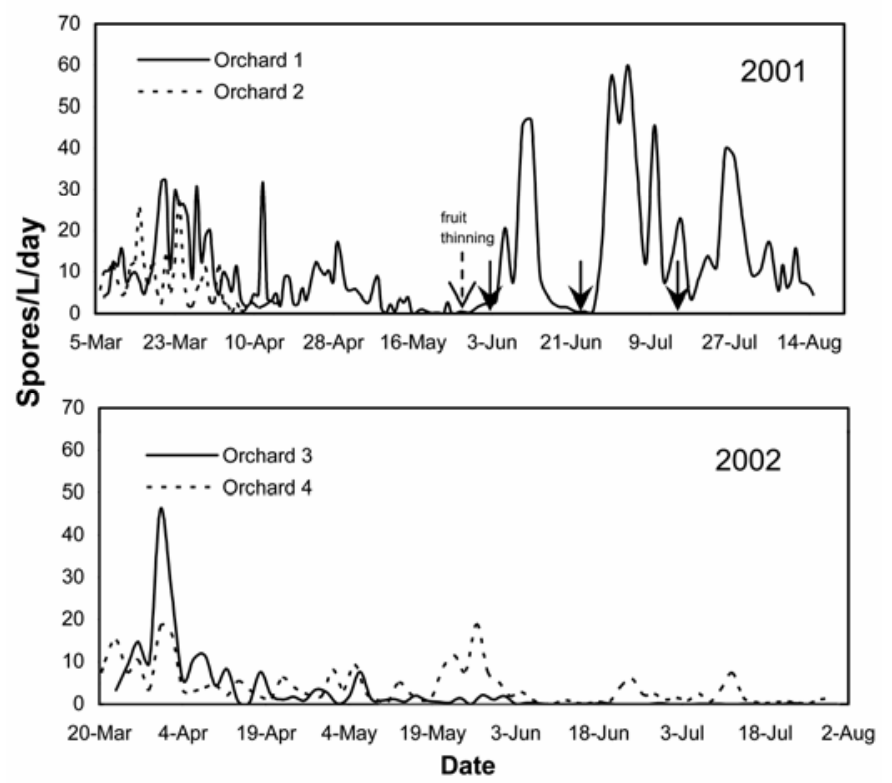

Fig. 1. Dynamics of daily spore concentration of Monilinia fructicola in the air as determined with Burkard spore traps in four prune orchards in California. Orchards 1 and 3 were located in Glenn County and orchards 2 and 4 were located in Tehama County. Average daily spore concentration was used in each curve. The dotted and solid arrows indicate the dates of fruit thinning and irrigation, respectively, in orchard 1.

\section{RESULTS}

Inoculum dynamics. Different patterns of dynamics of spore concentration in the air were observed across orchards and years (Fig. 1). In early March $2001, \approx 5$ spores (ascospores, conidia, or both)/liter/day were observed in each orchard. The spore concentration increased gradually with time, with peaks of plots occurring from late March to early April ( $\approx 30$ spores/liter/day), which coincided with full bloom of trees (23). Spore concentration decreased gradually after that period until May and was very low by the end of May. Differences in incidence of blossom infection between orchards were observed (Table 2). In orchard 1, fruit thinning was performed on 1 and 2 June, and irrigation began on 4 June 2001. After 5 to 7 days, spore concentration in the air started to increase, and the first peak of spore concentration appeared on 10 to 12 June, after the first irrigation. The spore concentration decreased dramatically to a very low level on 20 to 26 June. However, the second irrigation on 22 June and the third irrigation on 4 July were associated with two peaks of spore concentration in the air (Fig. 1). This observation suggested that moisture on the ground promoted sporulation on thinned fruit and increased inoculum in the orchard air. In orchard 1, 38.5\% of immature fruit had latent infections on the 22 July collection date (Table 2).

In spring 2002, no fruit thinning was implemented in orchards 3 and 4 . The spore concentrations in the air were generally similar in the two orchards, and the mean incidence of blossom infection was low (0.25 to $3.0 \%$ ) (Table 2). Compared with the spore concentration patterns for the rest of the season, relatively higher spore concentrations (20 to 45 spores/liter/day) in the two orchards were observed from late March to early April (Fig. 1). In orchard 3, the spore concentration decreased steadily through the beginning of June and remained at a very low level until the end of the season. In orchard 4, spore concentrations fluctuated but the peaks were low and occurred in late March and early June. No latent infections were detected in immature fruit in either of these orchards (Table 2).

Fruit inoculation experiments. In 2002, different fruit rot development rates were observed for different inoculation dates in the season (Fig. 2A). In general, the earlier the inoculation date, the slower the fruit rot development. A similar trend of fruit rot development was observed in 2004 (Fig. 2B). Linear regressions significantly $(P<0.0039)$ described the relationship between fruit

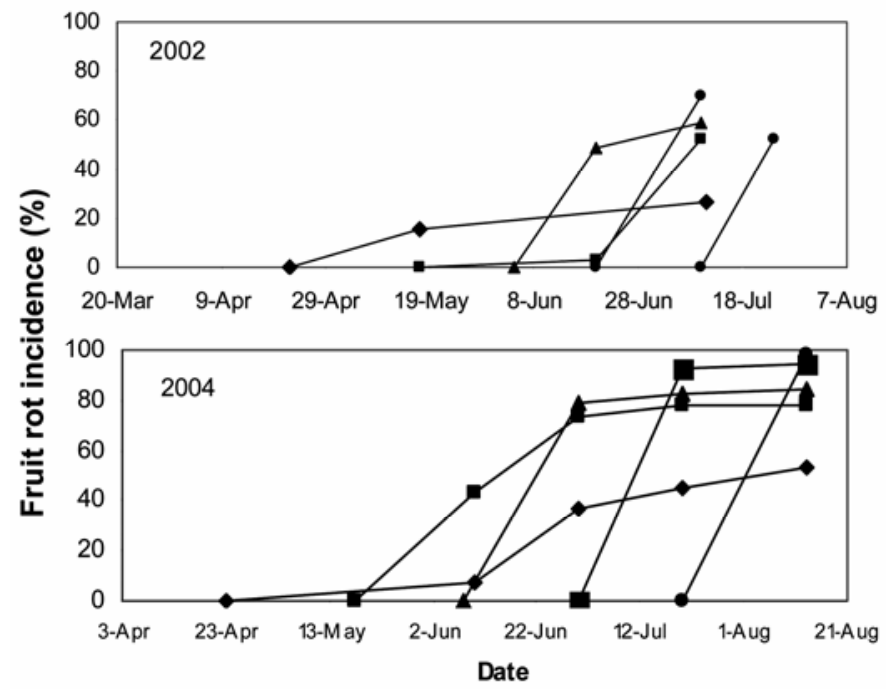

Fig. 2. Development of fruit rot incidence on branches of prune trees inoculated with conidia of Monilinia fructicola at different dates during 2002 and 2004. Each inoculation was conducted on 20 branches (total of $\approx 500$ to 600 fruit) in each of 10 prune orchards in California. Each dot represents the mean incidence of fruit rot on the corresponding inoculation date from these orchards. 
rot development rate (percent per day) and days after full bloom for both years (Fig. 3).

Natural infection of blossoms and fruit. The range of incidence levels of blossom infection in the 15 data sets was 0 to $1.4 \%$. The range of incidence levels of immature fruit infection at pit hardening, embryo growth, late embryo growth, before ripeness, and before first harvest were 0 to $21.6,0$ to 46,0 to 41,0 to 33 , and 0 to $52 \%$, respectively. The range of incidence of visible fruit rot 2 weeks before harvest was 0.0 to $1.0 \%$. The incidence of blossom infection did not correlate significantly with that of fruit latent infections on any sampling dates, or with the incidence of visible fruit rot (Table 3). However, the incidence of latent infection at the pit hardening stage correlated significantly with latent infection of fruit in late season (before ripeness and before first harvest) and with that of visible fruit rot (Table 3). After the pit hardening stage, the incidence levels of latent infection on all sampling dates significantly correlated with each other. However, only the incidence of latent infection in late season correlated significantly with that of visible fruit rot at harvest.

\section{DISCUSSION}

In this study, we found that spore concentration of $M$. fructicola in the air in prune orchards in California was at the highest level

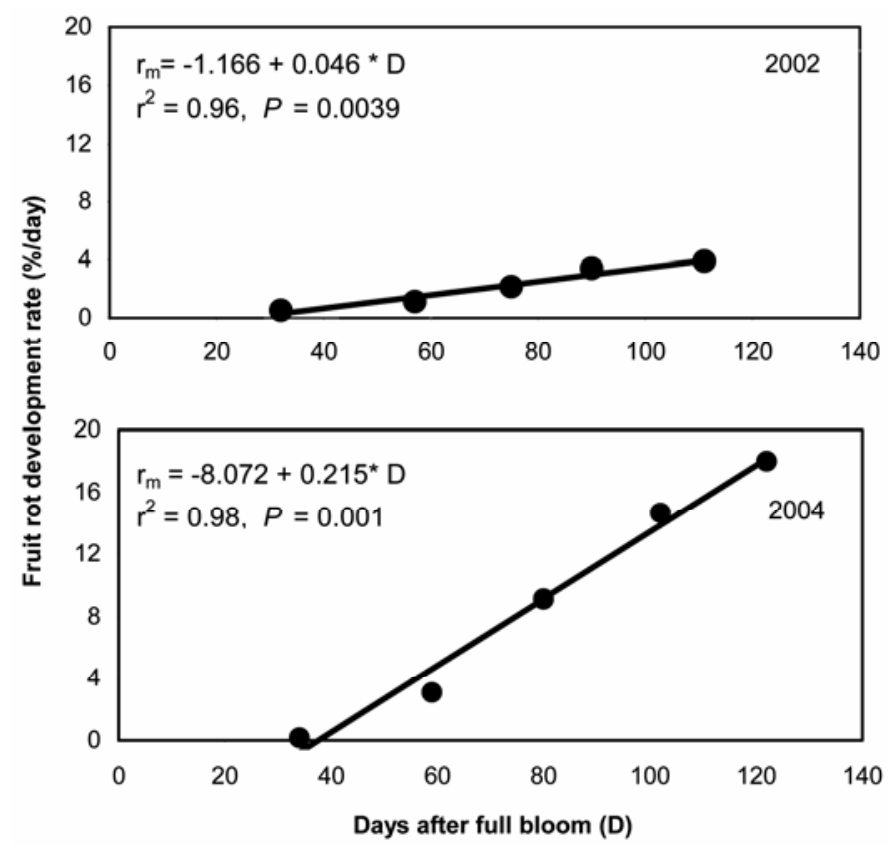

Fig. 3. Linear relationships between fruit rot development rate $\left(r_{m}\right)$ and inoculation time (D) on fruit inoculated with Monilinia fructicola. Each data point represents the mean fruit rot disease progress rate from 10 prune orchards estimated from 20 branches (total of $\approx 500$ to 600 fruit) in each orchard. during bloom and decreased gradually throughout the growing season. Latent infections of fruit in late season resulted in a higher risk of visible fruit rot than did those in early season. The fruit rot development rate increased linearly with the growing season. The incidence of latent fruit infection at the pit hardening stage correlated significantly with that at late stages and with the incidence of visible fruit rot at harvest. This information can be used to guide growers in making decisions on fungicide applications in mid- or late season.

In orchard 1, inoculum dynamics were affected by orchard management practices. When improper timing of fruit thinning and irrigation were implemented in this orchard with a high inoculum potential, the risk of fruit infection in midseason was very high. This is because a high incidence of latent infection in immature fruit leads to more fruit showing sporulation after thinning, assuming that moisture has been provided by irrigation or rain. In contrast, in orchards with low inoculum density, if proper timing of fruit thinning and irrigation are scheduled, the risk of fruit latent infection can be low.

Similar observations on initial inoculum levels were reported by Tate and Wood (25) for peach orchards in New Zealand. They reported that the ascospore concentration ranged from 0 to 39 spores/liter/day. In our study, we observed that the maximum spore concentration in spring (before 1 May) was 32 and 25 spores/liter/day in the respective orchards. However in our study, the period of spore dissemination from the beginning, the peak, and the decline lasted longer than in the study by Tate and Wood (25).

Current disease management strategies should take into account the inoculum dynamics in orchards along with the scheduling of fruit thinning and irrigation. In the Central Valley of California, where $>50 \%$ of prune orchards are located, the bloom season can coincide with the end of rainy season; thus, conditions usually are favorable for infection. After bloom, in general, the spore concentration in orchards may decrease, but there is still a risk of fruit infection, especially in orchards where the potential inoculum is high. If rain occurs just after fruit thinning during this period, the risk of latent infection of immature fruit on trees may increase because conidia become available from the thinned fruit and fruit on trees are at the most susceptible stage (14). A previous study (12) demonstrated that, when water content of thinned fruit decreased to $<20 \%$, only a small percentage of fruit could produce spores and for only a short period. Thus, if the water content of thinned fruit is reduced quickly, sporulation of the pathogen also would be reduced and the risk of latent infection would be minimal. Therefore, decisions on timing of irrigations need to be made according to the stage of fruit susceptibility to infection (14), the condition of thinned fruit in relationship to water content affecting sporulation of the pathogen (12), the corresponding microclimatic conditions $(14,15)$, the quantitative relationship between latent infection level and environment at different fruit developmental stages (14), and the threshold conditions that lead from latent infection to fruit rot (16).

TABLE 3. Correlation coefficients and the corresponding $P$ values among incidence levels of blossom or fruit infection by Monilinia fructicola in prune ${ }^{\mathrm{a}}$

\begin{tabular}{|c|c|c|c|c|c|c|c|}
\hline \multirow[b]{2}{*}{ Sampling stage ${ }^{b}$} & \multicolumn{6}{|c|}{ Latent } & \multirow{2}{*}{$\begin{array}{c}\text { Visible } \\
\begin{array}{c}\text { Fruit rot at } \\
\text { harvest }\end{array}\end{array}$} \\
\hline & $\begin{array}{c}\text { Full } \\
\text { bloom }\end{array}$ & $\begin{array}{c}\text { Pit } \\
\text { hardening }\end{array}$ & $\begin{array}{l}\text { Embryo } \\
\text { growth }\end{array}$ & $\begin{array}{l}\text { Late embryo } \\
\text { growth }\end{array}$ & $\begin{array}{l}\text { Before } \\
\text { ripeness }\end{array}$ & $\begin{array}{c}\text { Before first } \\
\text { harvest }\end{array}$ & \\
\hline Full bloom & 1.0000 & $0.2542(0.3605)$ & $0.3270(0.2342)$ & $0.3642(0.1820)$ & $0.4074(0.1318)$ & $0.3696(0.1751)$ & $0.2064(0.4605)$ \\
\hline Pit hardening & $\ldots$ & 1.00000 & $0.3734(0.1704)$ & $0.3993(0.1403)$ & $0.7427(0.0015)$ & $0.5636(0.0287)$ & $0.7299(0.0020)$ \\
\hline Embryo growth & $\ldots$ & $\ldots$ & 1.0000 & $0.9721(<0.0001)$ & $0.8253(0.0002)$ & $0.8401(<0.0001)$ & $0.4142(0.1248)$ \\
\hline Late embryo growth & $\ldots$ & $\ldots$ & $\ldots$ & 1.0000 & $0.8120(0.0002)$ & $0.8031(0.0003)$ & $0.3835(0.1582)$ \\
\hline Before ripeness & $\ldots$ & $\ldots$ & $\ldots$ & $\ldots$ & 1.0000 & $0.9328(<0.0001)$ & $0.8100(0.0003)$ \\
\hline Before first harvest & $\ldots$ & $\ldots$ & $\ldots$ & $\ldots$ & $\ldots$ & 1.0000 & $0.7915(0.0004)$ \\
\hline Visible fruit rot at harvest & $\ldots$ & $\ldots$ & $\ldots$ & $\ldots$ & $\ldots$ & $\ldots$ & 1.0000 \\
\hline
\end{tabular}

${ }^{a}$ Numbers $=$ correlation coefficient and numbers in parentheses $=P$ value.

b Data were from 15 prune orchards across 2 years. 
The incidence of blossom infection did not correlate with that of fruit rot at harvest in our study. Similarly, Zehr (28) indicated that blossom blight may affect infections of only immature fruit of early-maturing peach cultivars, but not of late-maturing cultivars. Also, Emery et al. (5) found no significant relationship between peach fruit rot incidence at harvest and blossom blight incidence in Georgia. In these studies, the effects of secondary infection caused by inoculum originating from thinned fruit may not have been taken into account. In our study, even in orchards without fruit thinning, we still found no correlation between incidence of blossom infection and fruit rot at harvest. This may have been due to the fact that blossoms at the full bloom stage were sampled to determine the incidence of blossom infection, but only a portion of blossoms will be fertilized to become young fruit. Additionally, survival of the pathogen's mycelia from latently infected blossoms through the stages of immature fruit may be affected by inhibitors such as phenolic acids (2).

The incidence of latent infection of immature fruit at the pit hardening stage (23) can be used practically to predict risk of fruit rot at harvest. Similarly, Emery et al. (5) found a high correlation between incidence of latent infection of peach at pit hardening and that of fruit rot at harvest. Based on the results of a previous study (16), a threshold of latent infection at pit hardening to estimate risk of fruit rot at harvest is at $\approx 5 \%$ incidence. If more than 5\% latent infection is detected in an orchard, a fungicide spray may be considered as early as possible (21). Michailides and Morgan (21) showed that early sprays (in May or June) also were effective in reducing brown rot because fruit-to-fruit contact was minimal and the coverage of fruit by the fungicides was better because the fruit did not develop the dense clustering (19). Additionally, reducing humidity late in the season may reduce the risk of fruit rot significantly. The recently adopted deficit irrigation practices may accomplish this goal (10).

The results of this study were used to develop a decision tree to help growers in timing of determination of latent fruit infection (13). Determination of the incidence of latent infection during mid-May and mid-June is strongly recommended for most situations in California prune orchards. When the inoculum potential is high and fruit thinning is implemented, determination of latent infection should be conducted earlier than in orchards where fruit thinning is not done. In orchards with low inoculum potential it may not be necessary to determine latent infection, or the time period to determine latent infection is comparatively later than in orchards with high inoculum potential. Although determination of latent infection after July is not strongly recommended, knowing the level of latent fruit infection in an orchard even after July may still be useful to schedule preharvest fungicide applications in late season to reduce risk of fruit rot at harvest (21), especially when a rain occurrence is forecasted before harvest.

\section{ACKNOWLEDGMENTS}

This study was supported by the California Dried Plum Board and United States Department of Agriculture CAR Grant 2002-51100-01990. We thank W. H. Olson (Cooperative Extension, Butte County), F. Niederholzer (Cooperative Extension, Yuba and Sutter Counties), G. S. Sibbett (Cooperative Extension, Tulare County), and B. A. Holtz (Cooperative Extension, Madera County) for their help in identifying prune orchards for this study; H. Reyes for helping with fruit inoculations in the various fields; and K. Lindauer, Z. Heath (Glenn County), C. Gilles (Tehama County), and D. Felts (Kearney Agricultural Center) for their help in spore trapping.

\section{LITERATURE CITED}

1. Biggs, A. R., and Northover, J. 1985. Inoculum sources for Monilinia fructicola in Ontario peach orchards. Can. J. Plant Pathol. 7:302-307.

2. Bostock, R. M., Wilcox, S. M., Wang, G., and Adaskaveg, J. E. 1999.
Suppression of Monilinia fructicola cutinase production by peach fruit surface phenolic acids. Physiol. Mol. Plant Pathol. 54:37-50.

3. Byrde, R. J. W., and Willetts, H. J. 1977. The Brown Rot Fungi of Fruit: Their Biology and Control. Pergamon Press, Oxford.

4. Cruickshank, R. H., and Wade, G. C. 1992. The activation of latent infections of Monilinia fructicola on apricots by volatiles from the ripening fruit. J. Phytopathol. 136:107-112.

5. Emery, K. M., Michailides, T. J., and Scherm, H. 2000. Incidence of latent infection of immature peach fruit by Monilinia fructicola and relationship to brown rot in Georgia. Plant Dis. 84:853-857.

6. Holtz, B. A., Michailides, T. J., and Hong, C. X. 1998. Development of apothecia from stone fruit infected and stromatized by Monilinia fructicola in California. Plant Dis. 82:1375-1380.

7. Hong, C. X., Holtz, B. A., Morgan, D. P., and Michailides, T. J. 1997. Significance of thinned fruit as a source of the secondary inoculum of Monilinia fructicola in California nectarine orchards. Plant Dis. 81:519-524.

8. Jerome, S. M. R. 1958. Brown rot of stone fruits: Latent contamination in relation to spread of the disease. J. Aust. Inst. Agric. Sci. 24:132-140.

9. Kable, P. F. 1965. Air dispersal of spores of Monilinia fructicola in peach orchards. Aust. J. Exp. Agric. Anim. Husb. 5:166-171.

10. Lampinen, B. D., Shackel, K. A., Southwick, S. M., Olson, W. H., and Dejong, T. M. 2004. Leaf and canopy level photosynthetic responses of French prune (Prunus domestica L. 'French') to stem water potential based deficit irrigation. J. Hortic. Sci. Biotechnol. 79:638-644.

11. Landgraf, F. A., and Zehr, E. 1982. Inoculum sources for Monilinia fructicola in South Carolina peach orchards. Phytopathology 72:185-190.

12. Luo, Y., Ma, Z., and Michailides, T. J. 2001. Analysis of factors affecting latent infection and sporulation of Monilinia fructicola on prune fruit. Plant Dis. 85:999-1003.

13. Luo, Y., and Michailides, T. J. 2001. Development of web site for brown rot of stone fruits and a decision support system for IPM of blossom blight of prune. Pages 53-59 in: 2001 Prune Res. Rep. Index Prune Res. California Prune Board, Pleasanton, CA.

14. Luo, Y., and Michailides, T. J. 2001. Factors affecting latent infection of prune fruit by Monilinia fructicola. Phytopathology 91:864-872.

15. Luo, Y., and Michailides, T. J. 2001. Risk analysis for latent infection of prune by Monilinia fructicola in California. Phytopathology 91:1197-1208.

16. Luo, Y., and Michailides, T. J. 2003. Threshold conditions leading latent infection to prune fruit rot caused by Monilinia fructicola. Phytopathology 93:102-111.

17. Luo, Y., Michailides, T. J., Morgan, D. P., Krueger, W. H., and Buchner, R. P. 2001. Prediction of brown rot of prune: Spore inoculum potential and threshold conditions leading latent infection to fruit rot caused by Monilinia fructicola. Pages 32-52 in: 2001 Prune Res. Rep. Index Prune Res. California Prune Board, Pleasanton, CA.

18. Luo, Y., Morgan, D. P., and Michailides, T. J. 2001. Risk analysis of brown rot blossom blight of prune caused by Monilinia fructicola. Phytopathology 91:759-768.

19. Michailides, T. J., and Morgan, D. P. 1997. Influence of fruit-to-fruit contact on the susceptibility of French prune to infection by Monilinia fructicola. Plant Dis. 81:1416-1424.

20. Michailides, T. J., Morgan, D. P., and Felts, D. 2000. Detection and significance of symptomless latent infection of Monilinia fructicola in California stone fruits. (Abstr.) Phytopathology 90(suppl.):S53.

21. Michailides, T. J., Morgan, D. P., Felts, D., and Krueger, W. 1997. Ecology and epidemiology of prune brown rot and new control strategies. Pages 109-123 in: 1996 Prune Res. Rep. Index Prune Res. California Prune Board, Pleasanton, CA.

22. Northover, J., and Cerkauskas, R. F. 1994. Detection and significance of symptomless latent infections of Monilinia fructicola in plums. Can. J. Plant Pathol. 16:30-36.

23. Polito, V. S. 1981. Flower and fruit development. Pages 46-52 in: Prune Orchard Management. D. E. Ramos, ed. Division of Agricultural Sciences, University of California, Berkeley.

24. Sholberg, P. L., Ogawa, J. M., and Manji, B. T. 1981. Diseases of Prune blossoms, fruits, and leaves. Pages 121-125 in: Prune Orchard Management. D. E. Ramos, ed. Division of Agricultural Sciences, University of California, Berkeley.

25. Tate, K. G., and Wood, P. N. 2000. Potential ascospore production and resulting blossom blight by Monilinia fructicola in unsprayed peach trees. N. Z. J. Crop Hortic. Sci. 28:219-224.

26. Wade, G. C., and Cruickshank, R. H. 1992. The establishment and structure of latent infections with Monilinia fructicola on apricot. J. Phytopathol. 136:95-106.

27. Zadoks, J. C., and Schein, R. D. 1979. Epidemiology and Plant Disease Management. Oxford University Press, New York.

28. Zehr, E. I. 1982. Control of brown rot in peach orchards. Plant Dis. 66:1101-1105. 